\title{
Pengaruh Dukungan Sosial dan Psychological Well Being terhadap Prestasi Belajar Santri Kelas X (Studi Kasus di MBS Sleman dan Ibnul Qoyyim Putri)
}

\author{
Nadzifah Fitriyani \\ Magister Studi Islam Universitas Muhammadiyah Yogyakarta \\ nadzifahfitri37@gmail.com
}

\begin{abstract}
Abstrak
Penelitian ini bertujuan untuk: 1) menganalisis pengaruh dukungan sosial terhadap prestasi belajar santri kelas X di MBS Sleman dan Ibnul Qoyyim Puteri ;2) mengkaji pengaruh PWB terhadap prestasi belajar santri kelas X di MBS Sleman dan Ibnul Qoyyim Puteri ;3) menemukan variabel yang lebih dominan mempengaruhi prestasi belajar antara dukungan sosial dan PWB.

Jenis penelitian menggunakan penelitian deskriptif korelasional dengan pendekatan kuantitatif. Lokasi penelitian adalah MBS Sleman dan Ibnul Qoyyim Puteri. Sampel di MBS Sleman sebanyak 29\% dari populasi 175,sampel 50 santri dan Ibnul Qoyyim Puteri sebanyak 67\% dari populasi 75, sampel juga 50 santri. Metode pengumpulan data menggunakan kuesioner, observasi, wawancara, dan dokumentasi. Datanya dianalisis menggunakan teknik ana lisis regresi.

Berdasarkan hasil penelitian bahwa: 1) dukungan sosial dan PWB berpengaruh terhadap prestasi belajar santri kelas X di MBS Sleman dan Ibnul Qoyyim Puteri. Dukungan sosial bersama-sama PWB memiliki persentase sumbangan pengaruh terhadap prestasi belajar sebesar 20,3\% di MBS Sleman dan 35,2\% di Ibnul Qoyyim Puteri. 2) Dukungan sosial berpengaruh terhadap prestasi belajar santri kelas X,baik di MBS Sleman $(p=0,002)$ dan Ibnul Qoyyim Puteri ( $p=0,034)$. 3) PWB tidak mempengaruhi prestasi belajar santri kelas X di MBS Sleman $(p=0,200)$ dan Ibnul Qoyyim Puteri ( $p=0,226)$. 4) Dukungan sosial lebih dominan dalam mempengaruhi prestasi belajar,baik di MBS Sleman dan Ibnul Qoyyim Puteri.
\end{abstract}

Kata Kunci: Dukungan Sosial, Psychological Well Being, Prestasi Belajar

\begin{abstract}
This research aims to: 1) analyze the effects of social support on the learning achievement of class X students at MBS Sleman and Ibnul Qoyyim Islamic female boarding school; 2) study the effects of psychological well-being on the the learning achievement of class X students at MBS Sleman and Ibnul Qoyyim Islamic female boarding school; 3) find out the most dominant variable influencing students learning achievement between social support and psychological well-being.

This type of research uses descriptive correlational research with a quantitative approach. The research location is MBS Sleman and Ibnul Qoyyim Princess. Samples in MBS Sleman were $29 \%$ of the population of 175 santri, so a sample of 50 santri. In Ibnul Qoyyim Puteri there were $67 \%$ of the population of 75 santri, so there were also 50 santri. Methods of collecting data using questionnaires, observation, interviews, and documentation. The data were analyzed using regression analysis techniques.
\end{abstract}


The findings reveal that: 1) Social effect has an effect on students'learning achievement at MBS Sleman and Ibnul Qoyyim Islamic female boarding school. Social support and psychological well-being have contributed to the students'learning achievement by 20,3\% at MBS Sleman and by 35,2\% at Ibnu Qoyyim Islamic female boarding school. 2) Social support affects the learning achievement of students of class X, both at MBS Sleman $(p=0.002)$ and Ibnul Qoyyim Islamic female boarding school $(p=0.034)$. 3) Psychological well-being has no effect on the learning achievement of class X students both at MBS Sleman $(p=0,200)$ and Ibnul Qoyyim Islamic female boarding school $(p=0,226)$. 4) Social support has more dominant effect on students'learning achievement both MBS Sleman and Ibnul Qoyyim Islamic female boarding school.

\section{Keywords: Social Support, Psychological Well-Being, Learning Achievement}

\section{PENDAHULUAN}

Setiap pendidik mengharapkan orang yang didiknya berhasil. Keberhasilan orang yang dididik dapat terlihat dari keberhasilannya menempuh ujian. Pada masa sekarang keberhasilan menempuh ujian dapat dilihat dari nilai-nilai yang disebut juga sebagai prestasi. Setiap lembaga pendidikan mengharapkan anak- didiknya berprestasi sebagai bukti bahwa lembaga pendidikan tersebut telah berhasil. Demikian juga pondok pesantren, walaupun berfokus pada kegiatan keagamaan juga mengharapkan agar anak didiknya yang disebut santriwan dan santriwati memiliki prestasi yang baik.

Beberapa pondok pesantren masih perlu melakukan usaha-usaha maksimal untuk dapat mencapai kondisi ideal tersebut. Hasil penelitian pendahuluan menunjukkan bahwa responden di MBS Sleman dan Ibnul Qoyyim Puteri memiliki prestasi belajar yang kurang optimal yaitu di MBS Sleman sebanyak 56\% dan Ibnul Qoyyim Puteri sebanyak 60\%.

Penentuan keberhasilan proses belajar mengajar di sekolah banyak melibatkan beberapa faktor yang mendukung. Keberhasilan tersebut dapat diukur melalui kegiatan evaluasi belajar yang merupakan salah satu faktor penentu prestasi belajar siswa. Prestasi belajar seorang siswa sebenarnya berkaitan dengan berbagai faktor-faktor, antara lain faktor internal maupun faktor eksternal. Secara sistematik faktor-faktor tersebut saling berpengaruh terhadap keberhasilan belajar. Salah satu faktor yang terkait dengan pencapaian prestasi siswa adalah faktor dukungan sosial.
Banyak perbedaan kehidupan antara pondok pesantren dengan kehidupan pendidikan di sekolah umum. Berbagai usaha dalam menghadapi permasalahan yang ada di pondok pesantren membuat santri akan mendapatkan pengalaman-pengalaman, baik pengalaman yang menyenangkan ataupun tidak menyenangkan, yang kemudian akan mempengaruhi kesejahteraan psikilogis atau psychological well being ${ }^{l}$. Penelitian dari North West Adelaide Health Study tentang tingkat psychological well being memberikan hasil bahwa 26\% dari 151 responden siswa memiliki tingkat psychological well being yang tinggi ${ }^{2}$.

Uraian tersebut menunjukkan adanya kemungkinan keterkaitan antara kondisi prestasi belajar dengan dukungan sosial dan psychological well being. Hasil dari angket penelitian pendahuluan di MBS Sleman diketahui bahwa $40 \%$ responden penelitian pendahuluan memiliki dukungan sosial yang rendah. Sebanyak $44 \%$ dari responden tersebut memiliki psycological well being yang rendah. Kondisi tidak jauh berbeda juga terjadi di Ibnul Qoyyim Puteri. Responden penelitian pendahuluan di lokasi tersebut cukup banyak yang memiliki dukungan sosial rendah (44\%).

${ }^{1}$ Halim dan Atmoko, Hubungan Antara Kecemasan akan HIV/AIDS dan Psychological Well Being pada Waria yang Menjadi Pekerja Seks Komersial. Jurnal Psikologi. Volume 15. No 1, 2005 hlm. 17-31

${ }^{2}$ North West Adelaide Health Study. Cronic Condition Psychological Well Being: Epidemiological Series Report. Australia: The University of Adelaide Australian. 2007 hlm. 23 
Responden tersebut juga memiliki psycological well being yang rendah (48\%). Hasil penelitian pendahuluan tersebut menunjukkan bahwa dukungan sosial dan psycological well being di kedua lokasi tersebut perlu ditelaah. Terlebih dalam kaitannya dengan prestasi belajar santri di kedua lokasi tersebut.

Data di atas diperkuat dengan keterangan beberapa santri di MBS Sleman dan Ibnul Qoyyim Puteri, menyatakan:

“.......kami tinggal di pondok pesantren bukan atas kemauan kami sendiri tetapi berdasarkan tuntutan dari orang tua dan kami tidak nyaman karena kami takut dengan pengasuh dan teman-teman yang karakternya beragam" (salah seorang santri).

Keterpaksaan tersebut juga ada berpengaruh terhadap hubungan mereka dengan lingkungan sekitar. Saat mereka sedang mempunyai suatu masalah, mereka hanya memendam masalah itu sendiri tanpa menceritakan kepada orang lain di sekitar. Mereka merasa susah untuk terbuka, kurang memperhatikan terhadap orang lain, merasa terasing dan frustasi dalam hubungan antarpribadi. Hal tersebut menunjukkan bahwa santri memiliki permasalahan terhadap hubungan positif dengan orang lain, dimana hubungan positif dengan orang lain merupakan salah satu hal yang membentuk psychological well being individu.

Berdasar latar belakang di atas, maka permasalahan yang akan dikaji dalam penelitian ini adalah pengaruh dukungan sosial dan psycological well being terhadap prestasi belajar santri di MBS Sleman dan Ibnul Qoyyim Puteri. Penelitian ini dilakukan pada santri kelas X di MBS Sleman dan Ibnul Qoyyim Puteri didasarkan pada latar belakang masalah sebelumnya. Diharapkan dari penelitian ini dapat memberikan solusi yang dapat memberikan dampak positif dari dukungan sosial dan psychological well being sehingga prestasi belajar santri kelas $\mathrm{X}$ akan meningkat.

\section{METODE PENELITIAN}

Jenis penelitian yang akan digunakan oleh peneliti adalah penelitian korelasional dengan menggunakan pendekatan kuantitatif. Penelitian regresi ditujukan untuk mengestimasi hubungan antara satu varibael tak bebas (dependent) dengan beberapa variabel bebas (independent). Pendekatan yang dilakukan oleh peneliti menggunakan pendekatan kuantitatif. Metode penelitian dengan menggunakan pengukuran dari masing-masing variabel yang ada kemudian dianalisis dengan menggunakan teknik analisis statistik untuk mencari pengaruh variabel dukungan sosial $\left(\mathrm{X}_{1}\right)$ dan variabel psychological well being $\left(\mathrm{X}_{2}\right)$ terhadap prestasi belajar (Y).

Lokasi penelitian ini adalah MBS Sleman dan Ibnul Qoyyim Puteri. Alasan memilih lokasi ini karena kedua sekolah tersebut berbasis boarding school yang bayak diminati oleh masyarakat dan merupakan memiliki basic dan latar belakang yang berbeda antara MBS Sleman dan Ibnul Qoyyim Puteri.

Populasi diartikan sebagai suatu wilayah generalisasi yang terdiri atas obyek atau subyek yang memiliki kualitas dan karakteristik tertentu yang ditetapkan oleh peneliti. ${ }^{3}$ Populasi yang digunakan adalah santri baru kelas $X$ di MBS Sleman sejumlah 175 santri baru dan Ibnul Qoyyim Puteri sejumlah 75 santri baru. Sampel merupakan bagian dari jumlah dan karakteristik yang dimiliki oleh populasi tersebut. ${ }^{4}$ Sedangkan, teknik pengambilan sampel yang digunakan adalah simple random sampling, karena pengambilan anggota sampel dari populasi ini dilakukan secara acak atau random tanpa melihat dan memperhatikan strata yang ada dalam populasi tersebut. Pengambilan sampel penelitian ini berdasarkan pada pendapat Arikunto, maka apabila jumlah subyek kurang dari 100 lebih baik digunakan dan diambil semua sehingga penentuannya penelitian populasi. Selanjutnya apabila jumlah subyek

${ }^{3}$ Sugiyono, Metode Penelitian Kombinasi (Mixed Methods) (Bandung: Alfabeta, 2015) hlm. 297

${ }^{4}$ Suharsimi, Prosedur Penelitian Suatu Pendekatan Praktik (Jakarta: Rineka Cipta, 2010) hlm. 174 
lebih dari 100 maka dapat diambil antara 10\%$15 \%, 20 \%-25 \%$, atau lebih 5 .

Berdasarkan hal tersebut, maka akan diambil sampel di MBS Sleman sebanyak 29\% dari populasi sejumlah 175 santri, sehingga jumlah sampel 50 santri. Sedangkan di Ibnul Qoyyim sebanyak 67\% dari jumlah populasi sejumlah 75 santri, sehingga sampel juga sebanyak 50 santri.

Variabel penelitian merupakan hal yang menunjukkan pada karateristik atau atribut dari suatu fenomena atau obyek yang dapat diukur dan diobservasi ${ }^{6}$. Variabel dalam penelitian ini ada tiga yakni dukungan sosial $\left(\mathrm{X}_{1}\right)$ dan psychological well being $\left(\mathrm{X}_{2}\right)$ sebagai variabel bebas, sedangkan variabel terikat yaitu prestasi belajar (Y). Metode pengumpulan data menggunakan kuesioner/angket, observasi, wanawncara dan dokumentasi. Skala pengukuran yang digunakan oleh peneliti adalah skala likert, karena skala likert digunakan untuk mengukur sikap, pendapat dan persepsi seseorang atau sekelompok orang mengenai fenomena sosial yang terjadi di lingkungan sekitar ${ }^{7}$.

Uji coba ini digunakan untuk mengetahui seberapa besar alat ukur dapat mengungkapkan data dengan tepat mengenai apa yang ingin diukur dan seberapa besar alat ukur tersebut menunjukkan kecermatan dan ketelitian pengukuran yang sebenarnya ${ }^{8}$. Ada dua uji coba alat ukur yang dapat dilakukan dalam penelitian ini, yaitu:

Validitas sebagai suatu alat ukur mengenai ketepatan dan kecermatan dalam melakukan suatu pengukuran sesuai dengan aspek yang diukurnya atau fungsi ukurnya9. Alat ukur yang digunakan untuk mengukur dukungan

${ }^{5}$ Suharsimi. Prosedur Penelitian Suatu Pendekatan Praktik Edisi Revisi VI (Jakarta: Rineka Cipta, 2006) hlm. 134

${ }^{6}$ Silalahi, Metode Penelitian Sosial Kuantitatif (Bandung: Refika Aditama, 2015) hlm.181.

${ }^{7}$ Sugiyono, Metode Penelitian Kuantitatif, Kualitatif dan R \& D (Bandung: Alfabeta, 2013) hlm. 92

${ }^{8}$ Azwar, Penyusunan Skala Psikologi Edisi II (Yogyakarta: Pustaka Pelajar, 2017) hlm. 76

${ }^{9}$ Sukmadinata, Metode Penelitian Pendidikan (Bandung: Remaja Rosdakarya, 2013) hlm. 228 sosial dan psychological well being terhadap prestasi belajar terlebih dahulu dilakukan uji coba kevalidannya. Dalam pengujian validitas angket ini peneliti menggunakan bantuan SPSS for windows versi 15.00 dengan metode pearson correlation.

Menurut Widoyoko bahwa koefisien korelasi dapat dilakukan dengan membandingkan harga rxy dan harga kritik. Adapun harga kritik untuk validitas butir instrumen adalah 0,30. Artinya bahwa rxy lebih besar dari 0,30 (rxy > $0,30)$, nomor butir tersebut dapat dikatakan valid. sebaliknya jika rxy $<0,30$, dapat disimpulkan bahwa nomor butir tersebut dikatakan tidak valid $^{10}$. Uji coba instrumen penelitian dilakukan pada penelitian pendahuluan.

Responden pada uji coba tersebut yaitu 25 santri baru MBS Sleman dan Ibnul Qoyyim Puteri. Responden dipilih dari populasi yang akan diteliti sehingga memiliki karakteristik yang cenderung sama dengan pupulasi penelitian. Uji validitas menunjukkan bahwa terdapat item-item yang perlu digugurkan karena tidak memenuhi standar yaitu korelasi 0,30 . Namun pada alat ukur psychological well being diketahui bahwa item yang gugur sebanyak mendekati sepertiga item yang ada, sehingga standar diturunkan menjadi 0,25.

Reliabilitas merupakan alat ukur yang digunakan untuk mengukur derajat keajegan atau konsistensi alat ukur yang digunakan. adapun uji reliabilitas angket ini peneliti menggunakan cronbach's alpha dengan program SPSS for windows versi 15.00. yang mana koefisien reliabilitas angket pada umumnya menggunakan patokan 0,70. Apabila rxy lebih besar dari 0,70, maka uji reliabilitas tersebut memiliki reliabilitas yang tinggi (reliable). Sebaliknya, jika rxy $<0,70$, maka uji reliabilitas tersebut dinyatakan belum memiliki reliabilitas yang tinggi (unreliable).

Uji reliabilitas alat ukur juga menggunakan alat bantu berupa program SPSS for windows versi 15.00. Hasil uji reliabilitas menunjukkan

${ }^{10}$ Widoyoko, Teknik Penyusunan Instrumen Penelitian (Yogyakarta: Pustaka Pelajar, 2012) hlm. 149 
bahwa Skala Dukungan Sosial memiliki koefisien reliabilitas sebesar 0,884 . Adapun Skala Psychological Well Being memiliki koefisien reliabilitas sebesar 0,818 . Koefisien reliabilitas kedua skala dalam penelitian ini telah memenuhi standar yang ditetapkan sebelumnya yaitu di atas 0,7 .

Analisis data yang akan digunakan dalam penelitian ini yakni melalui perhitungan statistik deskriptif dan uji regresi linier berganda. Adapun rumus regresi berganda adalah sebagai berikut:

$$
\mathbf{Y}=\mathbf{a}+\mathbf{b}_{1} \mathbf{X}_{1}+\mathbf{b}_{2} \mathbf{X}_{2}
$$

\section{Dimana:}

$\mathrm{Y} \quad=$ Prestasi Belajar

$\mathrm{X}_{1} \quad=$ Dukungan Sosial

$\mathrm{X}_{2} \quad=$ Psychological Well Being

$\mathrm{a} \quad=$ Konstanta Regresi

$\mathrm{b}_{1}, \mathrm{~b}_{2}=$ Koefisien Regresi dari Variabel $\mathrm{X}_{1}$ dan $\mathrm{X}_{2}$

\section{HASIL DAN PEMBAHASAN}

Profil Responden

Adapun gambaran kondisi santri baru di MBS Sleman berdasarkan kondisi responden penelitian sebagai berikut:

\section{Usia Santri}

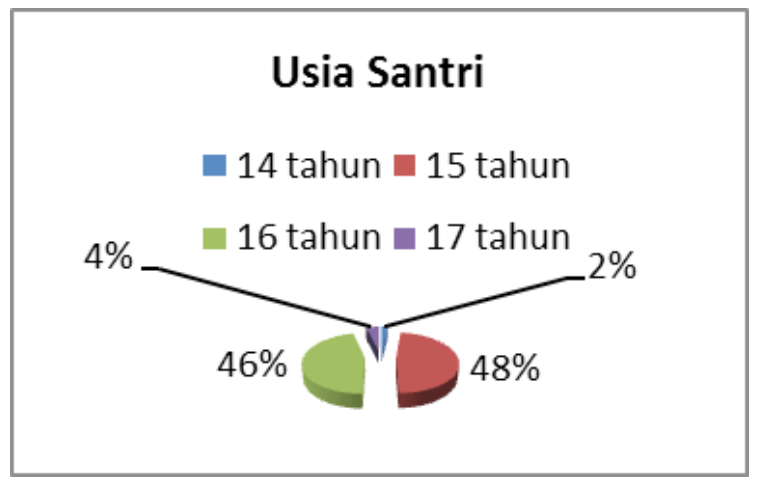

Gambar 1.1 Usia Santri MBS Sleman
Berdasarkan gambar grafik pie di atas dapat diketahui bahwa mayoritas santri MBS Sleman tersebut berusia 15-16 tahun.

\section{Pekerjaan orang tua}

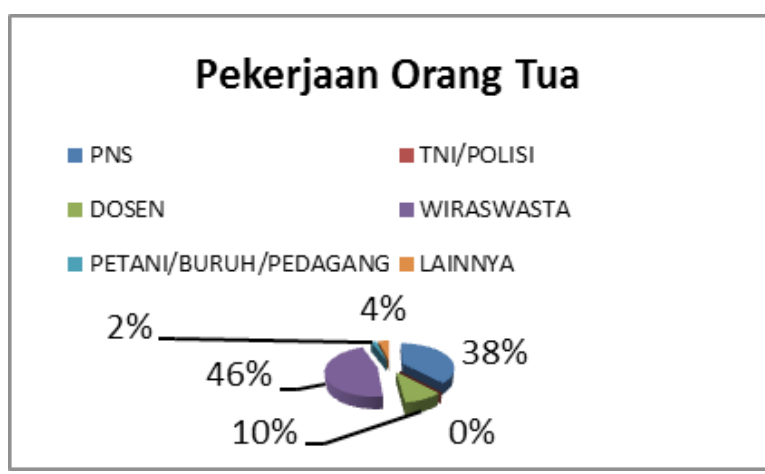

Gambar 1.2 Pekerjaan Orang tua santri MBS Sleman

Dari gambar grafik pie di atas dapat diketahui bahwa dapat dikatakan pekerjaan orang tua dari santri di MBS Sleman kebanyakan berprofesi sebagai wiraswasta.

\section{Asal sekolah}

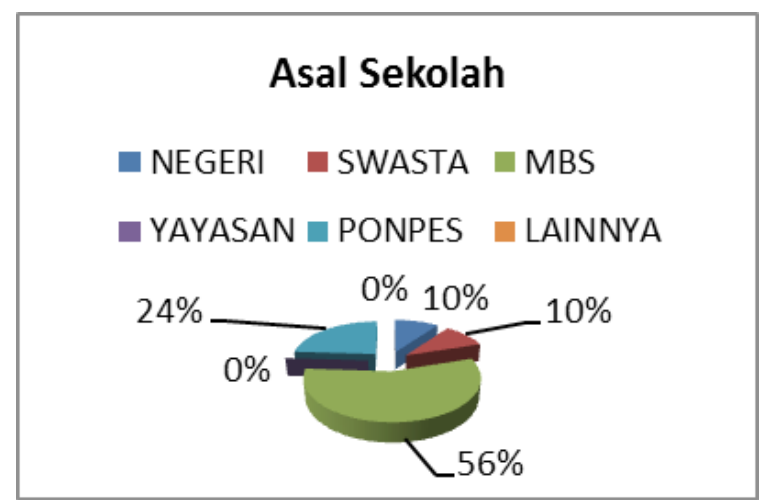

Gambar 1.3 Asal Sekolah santri MBS Yogyakarta

Pada gambar grafik pie di atas dapat dilihat bahwa kebanyakan santri di MBS Sleman berasal dari pendidikan sederajat SLTP di sekolah-sekolah tersebut.

Adapun gambaran kondisi santri baru di Ibnul Qoyyim Puteri berdasarkan kondisi responden penelitian ini sebagai berikut: 


\section{Usia Santri}

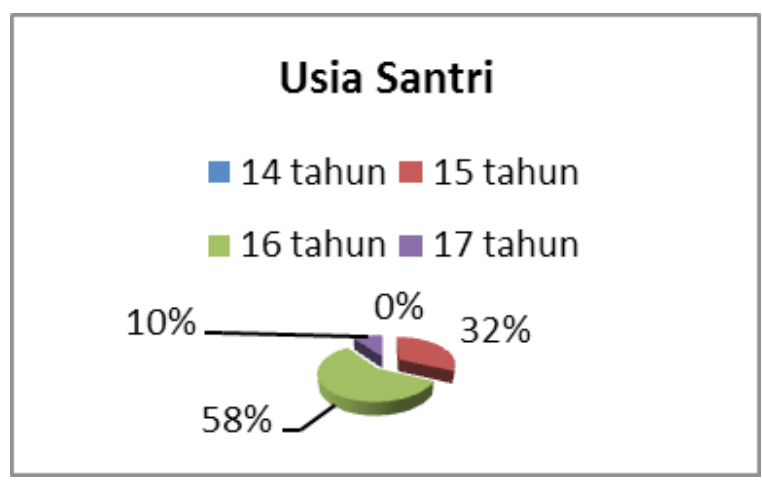

Gambar 1.4 Usia Santri di Ibnul Qoyyim Puteri

Berdasarkan gambar grafik pie di atas dapat diketahui bahwa mayoritas santri di Ibnul Qoyyim Puteri juga berusia 15-16 tahun.

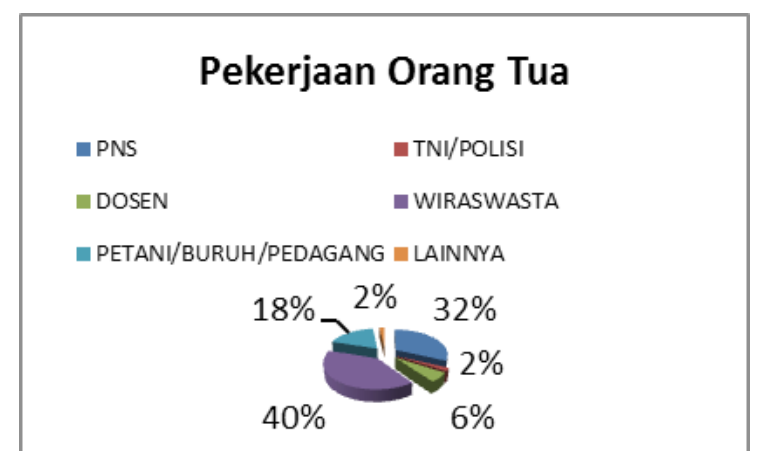

Gambar 1.5 Pekerjaan Orang tua santri di Ibnul Qoyyim Puteri

Dari gambar grafik pie di atas dapat dikatakan pekerjaan orang tua dari santri di Ibnul Qoyyim Puteri juga kebanyakan berprofesi sebagai wiraswasta.

\section{Asal sekolah}

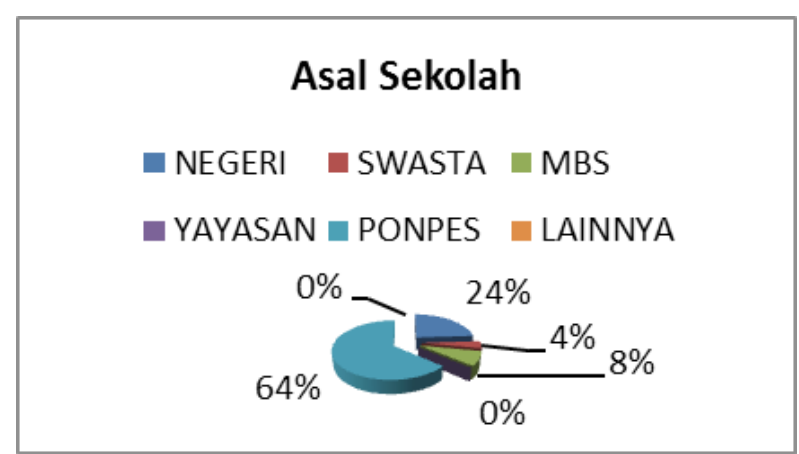

Gambar 1.6 Asal Sekolah santri Ibnul Qoyyim Puteri
Pada gambar grafik pie di atas dapat dilihat bahwa kebanyakan santri di Ibnul Qoyyim Puteri juga berasal dari pendidikan sederajat SLTP di sekolah-sekolah tersebut.

\section{Pengaruh Dukungan Sosial Terhadap Prestasi Belajar Santri}

\section{Hasil Angket Dukungan Sosial}

Berdasarkan hasil pengumpulan data dari MBS Sleman dan Ibnul Qoyyim Puteri, maka dapat dirumuskan kategorisasi kondisi dukungan sosial menjadi 5 kategori. Kategorisasi tersebut didasarkan pada rumusan masalah dengan menggunakan Mean dan Standar Deviasi Emiprik. Menentukan Kualifikasi dengan Skala Lima, sebagai berikut:

$$
\begin{aligned}
& M+1,5 . S D \\
& M+0,5 . S D \\
& M-0,5 . S D \\
& M-1,5 . S D
\end{aligned}
$$

Mean adalah rata-rata dari seluruh skor variabel $\mathrm{X}_{1}$ (dukungan sosial) dihitung dengan program SPSS dan didapatkan angka 108,94. SD adalah standar deviasi dari seluruh skor variabel $\mathrm{X}_{1}$ (dukungan sosial) dihitung dengan program SPSS dan didapatkan angka 8,582.

Adapun kategorisasi skor dukungan sosial untuk masing-masing responden akan dijelaskan sebagai berikut:

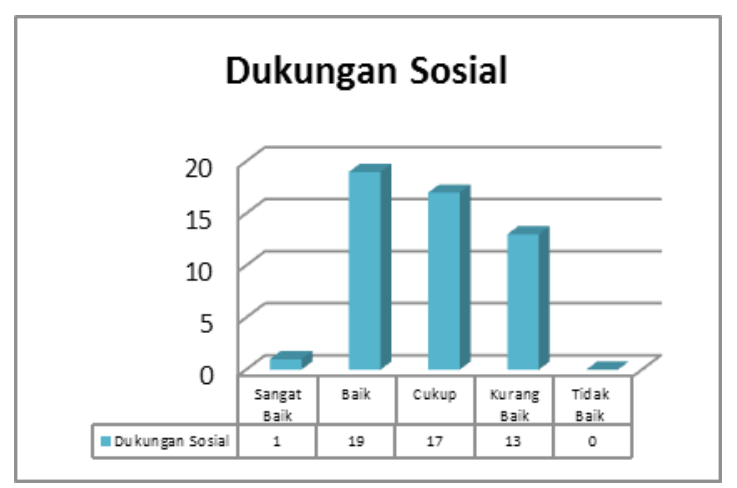

Gambar 1.7. Dukungan Sosial di MBS Sleman

Dari gambar grafik histogram di atas dapat diketahui bahwa dukungan sosial dari responden di MBS Sleman dengan kategori sangat baik sebanyak 1 santri, kategori baik 
sebanyak 19 santri, kategori cukup sebanyak 17 santri, kategori kurang baik sebanyak 13 santri dan tidak terdapat santri yang mendapatkan dukungan sosial dengan kategori tidak baik. Sehingga dapat dikatakan dukungan sosial santri di MBS Sleman kebanyakan dalam kategori baik.

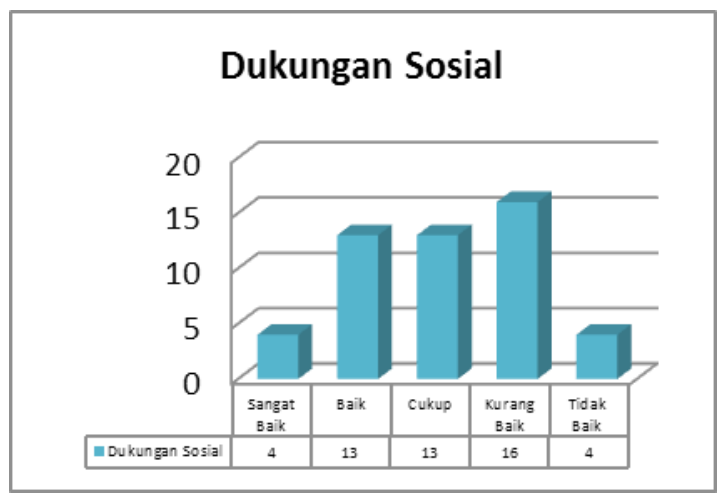

Gambar 1.8. Dukungan Sosial di Ibnul Qoyyim Puteri

Dari gambar grafik histogram di atas dapat diketahui juga bahwa dukungan sosial dari responden di Ibnul Qoyyim Puteri dengan kategori sangat baik sebanyak 4 santri, kategori baik sebanyak 13 santri, kategori cukup sebanyak 13 santri, kategori kurang baik sebanyak 16 santri dan kategori tidaak baik sebanyak 4 santri. Sehingga dapat dikatakan dukungan sosial santri di Ibnul Qoyyim Puteri dalam kategori kurang baik.

\section{Hasil Prestasi Belajar Santri}

Berdasarkan hasil pengumpulan data dari MBS Sleman dan Ibnul Qoyyim Puteri, maka dirumuskan kategorisasi prestasi belajar menjadi 5 kategori.

Mean adalah rata-rata dari seluruh skor variabel Y dihitung dengan program SPSS dan didapatkan angka 74,49. SD adalah standar deviasi dari seluruh skor variabel Y dihitung dengan program SPSS dan didapatkan angka 3,863 .

Adapun kategorisasi skor prestasi belajar untuk masing-masing responden akan dijelaskan sebagai berikut:

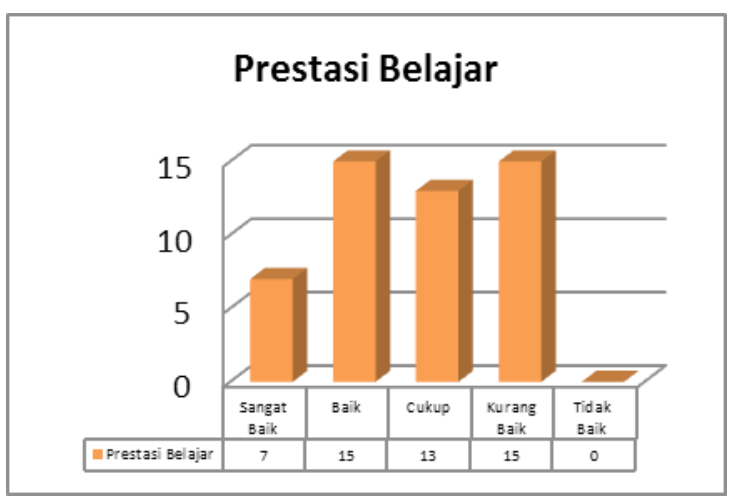

Gambar 1.9. Prestasi Belajar santri MBS Sleman

Dari gambar grafik histogram di atas dapat diketahui bahwa prestasi belajar dari responden di MBS Sleman dengan kategori sangat baik sebanyak 7 santri, kategori baik sebanyak 15 santri, kategori cukup sebanyak 13 santri, kategori kurang baik sebanyak 15 santri dan tidak terdapat santri yang mendapatkan prestasi belajar dengan kategori tidak baik. Sehingga dapat dikatakan prestasi belajar santri di MBS Sleman yang berada dalam kategori kurang baik dan tidak baik sebanyak 30\%.

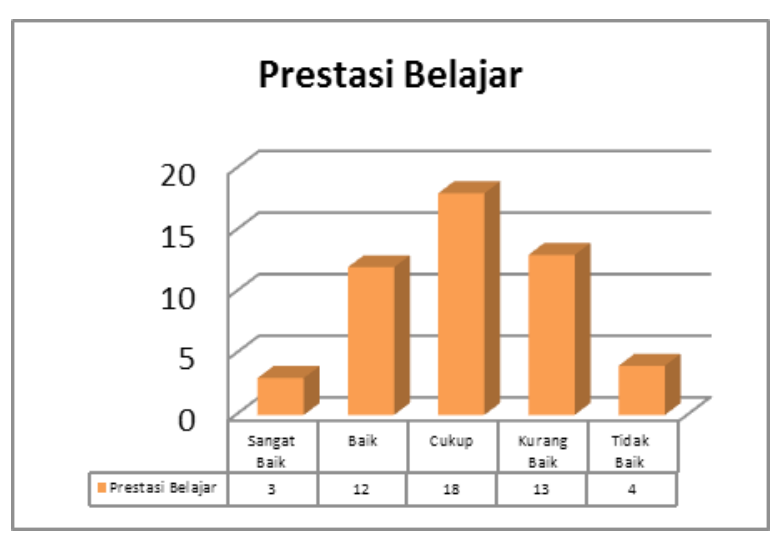

Gambar 1.10. Prestasi Belajar di Ibnul Qoyyim Puteri

Dari gambar grafik histogram di atas dapat diketahui juga bahwa prestasi belajar dari responden di Ibnul Qoyyim Puteri dengan kategori sangat baik sebanyak 3 santri, kategori baik sebanyak 12 santri, kategori cukup sebanyak 18 santri, kategori kurang baik sebanyak 13 santri dan kategori tidaak baik sebanyak 4 santri. Sehingga dapat dikatakan prestasi belajar santri di Ibnul Qoyyim Puteri 
yang berada dalam kategori kurang baik dan tidak baik sebanyak $34 \%$.

\section{Uji Pengaruh Dukungan Sosial Terhadap Prestasi Belajar}

Sebelum dilakukan uji pengaruh regresi linier berganda dengan alat bantu program SPSS for windows versi 15.00 dilakukan uji prasyarat, meliputi:

\section{Uji Multikolonieritas}

Data responden di Muhammadiyah Borading School Sleman menunjukkan bahwa kedua variabel independent memiliki korelasi $-0,579$ atau sebesar $57,9 \%$. Korelasi tersebut masih dibawah $95 \%$ sehingga dapat dikatakan dalam model yang akan diujikan tidak terjadi multikolonieritas yang serius. Adapun data responden di Ibnul Qoyyim Puteri menunjukkan bahwa kedua variabel independent memiliki korelasi $-0,770$ atau sebesar $77 \%$. Korelasi tersebut masih dibawah 95\% sehingga dapat dikatakan dalam model yang akan diujikan juga tidak terjadi multikoleritas yang serius.

\section{Uji Autokeralasi}

Karena jumlah variabel independent 2 $(\mathrm{K}=2)$ dan jumlah sampel lebih besar dari 40 dengan taraf signifikasi 5\%, maka kita peroleh nilai dl tabel 1,391 dan du tabel 1,600.

Data responden Muhammadiyah Borading School Sleman menunjukkan bahwa DW sebesar 2,212. Sedangkan data responden Ibnul Qoyyim Puteri menunjukkan bahwa DW sebesar 1,813. Dengan demikian nilai $\mathrm{DW}>$ nilai $\mathrm{du}(1,600)$ dan $<4$-du. Sehingga dapat dikatakan model terbebas dari masalah autokorelasi.

\section{Uji Heteroskedastisitas}

Berdasarkan regresi AbsUt data dari Muhammadiyah Borading School Sleman dan Ibnul Qoyyim Puteri terlihat bahwa hasil kedua variabel independent tidak ada yang signifikan. Dengan demikian model regresi yang digunakan terhindar dari masalah heteroskedastisitas.

\section{Uji Normalitas}

Analisis data dari Muhammadiyah Borading School Sleman menujukkan bahwa nilai K-S adalah 0,719 dengan signifikansi 0,679 sehingga nilai KS tidak signifikan. Hal ini menunjukkan bahwa residual terdistribusi secara normal. Adapun data dari Ibnul Qoyyim Puteri menujukkan bahwa nilai K-S adalah 0,556 dengan signifikansi 0,917 sehingga nilai KS tidak signifikan. Hal ini juga menunjukkan bahwa residual terdistribusi secara normal.

Setelah diketahui data yang akan dianalisis memenuhi syarat asumsi klasik, maka dapat dilakukan uji hipotesis uji regresi berganda. Pada data dari MBS Sleman menunjukkan besaran Adjusted R Square adalah 0,169 berarti 16,9\% variasi nilai pada santri MBS Sleman dijelaskan oleh variabel dukungan sosial dan psychological well being. Dari uji ANOVA didapat nilai F Hitung sebesar 5,978 dan signifikan. Dengan demikian dapat dikatakan jika secara bersama-sama variabel independen berpengaruh terhadap prestasi belajar santri kelas X MBS Sleman. Berdasarkan hasil dari uji $t$ terlihat bahwa hanya variabel dukungan sosial yang berpengaruh signifikan terhadap prestasi belajar santri kelas X di MBS Sleman $(\mathrm{p}=0,002)$.

Adapun data dari Ibnul Qoyyim Puteri menunjukkan besaran Adjusted R Square adalah 0,324 berarti $32,4 \%$ variasi nilai pada santri Ibnul Qoyyim dijelaskan oleh variabel dukungan sosial dan psychological well being. Dari uji ANOVA didapat nilai F Hitung sebesar 12,751 dan signifikan. Dengan demikian dapat dikatakan jika secara bersama-sama variabel independen berpengaruh terhadap prestasi belajar santri kelas X Ibnul Qoyyim Puteri. Berdasarkan hasil dari uji t terlihat bahwa hanya variabel dukungan sosial yang berpengaruh signifikan terhadap prestasi belajar santri kelas $X$ di Ibnul Qoyyim Puteri $(p=0,034)$.

Hasil analisis tersebut menujukkan bahwa diterima, karena uji ANOVA menunjukkan hasil yang signifikan. Dengan kata lain, terdapat pengaruh yang positif dukungan sosial dan psychological well being terhadap prestasi belajar santri. 
Dari analisis regresi linier berganda dapat dibuat rumusan hubungan variabel dependen dengan variabel independen. Berdasarkan analisis yang telah dilakukan diketahui bahwa hubungan variabel dependen dan variabel independen pada santri Muhammadiyah Borading School Sleman yaitu:

$$
Y=52,403+0,259 X_{1}-0,67 X_{2}
$$

Adapun rumusan hubungan variabel dependen dengan variabel independen. Berdasarkan analisis yang telah dilakukan diketaui bahwa hubungan variabel dependen dan variabel independen pada santri Ibnul Qoyyim puteri yaitu:

$$
Y=46,356+0,172 X_{1}+0,102 X_{2}
$$

Dimana:

$$
\begin{array}{ll}
\mathrm{Y} & =\text { Prestasi Belajar } \\
\mathrm{X}_{1} & =\text { Dukungan Sosial } \\
\mathrm{X}_{2} & =\text { Psychological Well Being }
\end{array}
$$

Hasil analisis terhadap data yang telah dilakukan dapat menjawab pertanyaan penelitian yang diajukan. Analisis menunjukkan ada pengaruh dukungan sosial terhadap prestasi belajar, baik di MBS Sleman maupun Ibnul Qoyyim Puteri.

Jadi penelitian ini sesuai dengan hasil peneitian sebelumnya bahwa dukungan sosial mempengaruhi prestasi belajar. Penelitian sebelumnya tersebut ${ }^{11}$ menunjukkan bahwa terdapat hubungan yang kuat antara dukungan sosial terhadap prestasi akademik, baik dalam bentuk dukungan instrumental maupun dukungan emosional. Hal ini menunjukkan bahwa adanya rasa nyaman, dihargai dan pengakuan dari lingkungan memberi dampak positif bagi kondisi psikis siswa dan menjadi situasi awal yang baik bagi kondisi siswa dalam

\footnotetext{
${ }^{11}$ Maslihah, Studi Tentang Hubungan Dukungan Sosial, Penyesuaian Sosial Di Lingkungan Sekolah Dan Prestasi Akademik Siswa Smpit Assyfa Boarding School Subang Jawa Barat (Jurnal Psikologi Undip Vol 10, No 2, Oktober 2011) hlm. 12
}

menerima pembelajaran. Kontinuitas dukungan ini, memberikan dampak positif tidak hanya ketika siswa menerima pelajaran tetapi berlanjut pada saat siswa menghadapi masa evaluasi pembelajaran.

Penelitian tersebut juga menjelaskan bahwa tanpa kehadiran dukungan sosial, maka prestasi akademikpun akan semakin menurun. Meskipun dukungan sosial komponen dukungan akan penghargaan dan adanya kasih sayang orang tua menunjukkan dukungan sosial terbesar diantara komponen dukungan lain yang dipersepsi siswa, namun secara umum bentuk instrumental support menunjukkan korelasi yang lebih kuat dengan prestasi akademik dibandingkan dengan hubungan prestasi akademik dengan emotional support. Artinya, adanya dukungan sosial orang tua saat siswa menghadapi kesulitan atau membutuhkan bantuan terutama kesulitan berkaitan dengan sekolah memiliki hubungan yang signifikan dengan pencapaian prestasi akademik siswa. Dengan kata lain, siswa tidak cukup mendapat dukungan yang bersifat emosional atau psikhis tetapi dukungan sosial atau responsivitas orang tua dalam bentuk bantuan, nasihat ataupun bimbingan langsung saat ia menghadapi kesulitan terutama kesulitan yang berkaitan dengan pendidikan atau sekolah memberikan dampak yang cukup besar bagi siswa terutama bagi pencapaian prestasi akademik siswa ${ }^{12}$.

Kondisi dukungan sosial tersebut mengindikasikan bahwa untuk mendapatkan prestasi belajar yang optimal santri juga membutuhkan situasi psikis yang nyaman yang dapat disebut juga psychological well being. Hal ini diperkuat dengan penelitian sebelumnya bahwa dukungan sosial berhubungan dengan psychological well being.

${ }^{12}$ Maslihah, Studi Tentang Hubungan Dukungan Sosial, Penyesuaian Sosial Di Lingkungan Sekolah Dan Prestasi Akademik Siswa Smpit Assyfa Boarding School Subang Jawa Barat (Jurnal Psikologi Undip Vol 10, No 2, Oktober 2011) hlm. 12 


\section{Pengaruh Pscyhological Well Being Terhadap Prestasi Belajar Santri}

\section{Hasil Angket pscyhological well being}

Berdasarkan hasil pengumpulan data dari MBS Sleman dan Ibnul Qoyyim Puteri, maka dirumuskan kategorisasi kondisi pscyhological well being menjadi 5 kategori.

Mean adalah rata-rata dari seluruh skor variabel $\mathrm{X}_{2}$ (psychological well being) dihitung dengan program SPSS dan didapatkan angka 86,78. SD adalah standar deviasi dari seluruh skor variabel $\mathrm{X}_{2}$ (psychological well being) dihitung dengan program SPSS dan didapatkan angka 9,882 .

Adapun kategorisasi skor psychological well being untuk masing masing responden akan dijelaskan sebagai berikut:

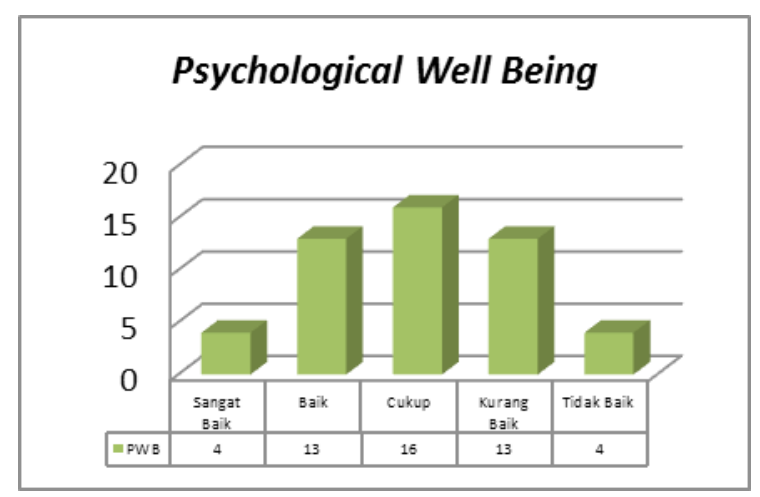

Gambar 1.11. Psychological well being santri MBS Sleman

Dari gambar grafik histogram di atas dapat diketahui bahwa psychological well being dari responden di MBS Sleman dengan kategori sangat baik sebanyak 4 santri, kategori baik sebanyak 13 santri, kategori cukup sebanyak 16 santri, kategori kurang baik sebanyak 13 santri dan kategori tidak baik sebanyak 4 santri. Sehingga dapat dikatakan pscyhological well being di MBS Sleman dalam kategori cukup.

Dari gambar grafik histogram di atas dapat diketahui juga bahwa psychological well being dari responden di Ibnul Qoyyim Puteri dengan kategori sangat baik sebanyak 3 santri, kategori baik sebanyak 14 santri, kategori cukup sebanyak 18 santri, kategori kurang baik

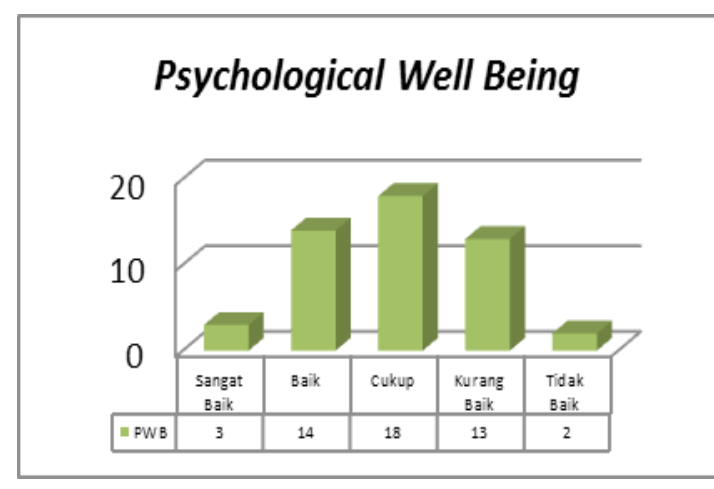

Gambar 1.12. Psychological well being santri Ibnul Qoyyim Puteri

sebanyak 14 santri dan kategori tidaak baik sebanyak 2 santri. Sehingga dapat dikatakan psychological well being di Ibnul Qoyyim Puteri juga dalam kategori cukup.

\section{Uji Pengaruh Psychological Well Being Terhadap Prestasi Belajar}

Merujuk pada hasil analisis bagian B point 3, berdasarkan analisis parsial bahwa psychological well being tidak berpengaruh secara signifikan terhadap prestasi belajar, baik di MBS Sleman maupun Ibnul Qoyyim Puteri.

Penelitian sebelumnya juga menunjukkan bahwa terdapat hubungan positif yang signifikan antara dukungan sosial dengan psychological well being. Hubungan tersebut berarti bahwa semakin tinggi dukungan sosial maka semakin tinggi psychological well being, dan sebaliknya semakin rendah dukungan sosial maka semakin rendah psychological well being. Psychological well being yang tinggi mengindikasikan bahwa sebagian besar dapat menerima keadaan dirinya dengan baik, mampu membentuk hubungan akrab dengan orang lain, mampu mengontrol lingkungan, memiliki kemandirian ${ }^{13}$.

Penelitian ini justru menunjukkan hal yang berbeda bahwa hubungan dukungan sosial dan psychological well being tidak kuat. Ini terlihat dari uji asumsi yang telah dilakukan. Bahkan pada penelitian ini hubungan kedua

${ }^{13}$ Musthafa, A.I.I \& Widodo, P.B. Psychological Well Being Ditinjau dari Dukungan Sosial pada Santriwan-Santriwati di Yayasan Al-Burhan Hidayatullah Semarang. (Jurnal Psychology) hlm. 5 
variabel adalah hubungan negatif yaitu semakin tinggi dukungan sosial, maka semakin rendah tingkat psychological well being. Perbedaan penelitian ini dengan penelitian sebelumnya dapat diakibatkan karena psychological well being merupakan kondisi psikologi seseorang yang santai dan tenang. Sedangkan kondisi dukungan sosial merupakan kondisi tenang yang didapatkan dari dukungan eksternal.

Dalam hal prestasi belajar seseorang dengan psychological well being yang tinggi dapat merasa tenang menghadapi ujian walaupun mereka belum siap atau belum mampu, sehingga pada akhirnya mereka tidak memperoleh prestasi belajar yang optimal. Adapun seseorang yang memiliki dukungan sosial yang baik merasa terdukung oleh lingkungan sehingga memiliki keinginan untuk menunjukkan prestasi kepada lingkungan.

Penjelasan tersebut didukung temuan sebelumnya bahwa hubungan psychological well being dan prestasi masih tidak jelas, kadang posistif dan kadang negatif. Kemungkinan ada faktor yang yang memoderasi atau memediasi hubungan psychological well being dan prestasi ${ }^{14}$. Beberapa hal yang mempengaruhi psychological well being dan prestasi yaitu keterlibatan, harga diri, keadilan organisasi, hubungan interpersonal dengan guru, persepsi siswa tentang sekolah dan motif menghadiri sekolah dapat memoderasi atau memediasi hubungan antara kesejahteraan dan prestasi akademik $^{15}$. Temuan lain juga menunjukkan bahwa dukungan orang tua mempengaruhi hubungan antara psychological well being dan prestasi. Artinya tanpa dukungan orang tua, tidak ada hubungan psychological well being dan prestasi $i^{16}$.

${ }^{14}$ Rüppel, F, dkk. The Influence of Psychological Well-Being on Academic Success. (J Public Health (2015) 23:15-24. DOI 10.1007/s10389-015-0654-y. 2015) hlm. 18

${ }^{15} \mathrm{Gräbel}$, B.F. 2017. The relationship between Wellbeing and Academic Achievement. (Positive Psychology and Technology Department of Behavioral, Management \& Social Sciences University of Twente. 2017) hlm. 11

${ }^{16} \mathrm{LvI}, \mathrm{B}, \mathrm{dkk}$. The Relationship between
Sesuai dengan hasil penelitian ini bahwa kondisi inilah yang menentukan dinamika hubungan antara dukungan sosial dan psychological well being dengan prestasi belajar. Hasil penelitian ini menunjukkan bahwa dukungan sosial menentukan prestasi belajar, tetapi psychological well being tidak menentukan prestasi belajar. Dapat dikatakan bahwa psychological well being bukanlah faktor penentu prestasi belajar.

\section{Variabel Yang Dominan Mempengaruhi Prestasi Belajar}

Dari analisis bagian B dan C dapat terlihat bahwa dukungan sosial lebih dominan dalam mempengaruhi prestasi belajar karena ketika psychological well being berdiri sendiri tidak mempengaruhi prestasi belajar. Psychological well being harus disertai dukungan sosial sehingga akan berpengaruh terhadap prestasi belajar. Dapat disimpulkan dukungan sosial lebih dominan dalam mempengaruhi prestasi belajar dibandingkan psychological well being.

Hasil uji F menunjukkan bahwa baik pada santri Muhammadiyah Borading School Sleman maupun santri Ibnul Qoyyim Puteri, dukungan sosial dan psychological well being secara bersama-sama dapat mempengaruhi prestasi belajar. Hasil uji t parsial menunjukkan dukungan sosial secara parsial dapat mempengaruhi prestasi belajar, namun psychological well being secara parsial tidak dapat mempengaruhi prrstasi belajar. Hal ini sama terjadi pada santri di Muhammadiyah Borading School Sleman maupun pada santri di Ibnul Qoyyim Puteri. Hasil analisis tersebut dapat menjawab pertanyan penelitian mengenai manakah yang lebih dominan mempengaruhi prestasi belajar antara dukungan sosial dan psychological well being.

Dinamika yang telah dijelaskan mengenai hubungan dukungan sosial dan psychological well being dengan prestasi belajar sesuai

Academic Achievement and the Emotional Well-Being of Elementary School Children in China: The Moderating Role of Parent-School Communication. (Frontiers in Psychology Volume 7. Article 948. 2016) h. 4. 
dengan teori yang ada bahwa diantara faktor yang menentukan prestasi belajar yaitu faktor eksternal berupa kondisi lingkungan yang mendukung dan faktor internal yaitu minat serta motivasi belajar ${ }^{17}$. Demikian menurut teori ahli belajar Bandura bahwa individu yang diarahkan dengan saran, nasihat dan bimbingan dapat meningkatkan kemampuannya yang dimilikinya sehingga membantu individu tersebut mencapai tujuan yang diinginkan ${ }^{18}$. Artinya, ketika seseorang mendapatkan dukungan sosial, ia dapat meningkatkan kemampuannya sehingga dapat meningkatkan prestasi.

\section{KESIMPULAN}

Berdasarkan hasil analisis dan pembahasan, maka kesimpulan yang dapat disusun pada penelitian ini sebagai berikut:

1. Dukungan sosial dan pscyhological well being memiliki pengaruh terhadap prestasi belajar santri kelas X di MBS Sleman dan Ibnul Qoyyim Puteri. Dukungan sosial bersama-sama pscyhological well being memiliki persentase sumbangan pengaruh terhadap prestasi belajar sebesar $20,3 \%$ di MBS Sleman dan 35,2\% di Ibnul Qoyyim Puteri.

2. Dukungan sosial berpengaruh terhadap prestasi belajar santri kelas X, baik di MBS Sleman $(p=0,002)$ dan Ibnul Qoyyim Puteri $(\mathrm{p}=0,034)$.

3. Psychological well being tidak mempengaruhi prestasi belajar santri kelas $X$, baik di MBS Sleman $(p=0,200)$ dan Ibnul Qoyyim Puteri $(\mathrm{p}=0,226)$.

4. Berdasarkan kesimpulan 2 dan 3, terlihat bahwa dukungan sosial lebih dominan dalam mempengaruhi prestasi belajar, baik di MBS Sleman dan Ibnul Qoyyim Puteri.

\footnotetext{
${ }^{17}$ Gunarsa, S.D. \& Gunarsa, Y.S, Psikologi Remaja. (Jakarta: BPK Gunung Muliat, 2000) hlm. 25

${ }^{18}$ Widanarti, N \& Indati, A, Hubungan Antara Dukungan Sosial Keluarga Dengan Self Efficacy Pada Remaja di SMUNegeri 9 Yogyakarta. Universitas Gadjah Mada (Jurnal Psikologi, No. 2, ISSN : 0215-8884, 112 -123. 2002) hlm. 116.
}

Berdasarkan hasil penelitian yang telah diperoleh, beberapa saran yang dapat diberikan kepada pihaak antara lain sebagai berikut:

1. Penelitian selanjutnya perlu menelaah dinamika mengenai hubungan dukungan sosial dan psychological well being dengan melihat keterkaitan aspek-aspeknya.

2. Sekolah dapat terus mengembangkan sistem ujian atau cara meningkatkan psychological well being yang memberikan tekanan pada santri untuk terus maju selama sekolah dapat memberikan dukungan sosial terhadap santri.

3. Untuk penelitian selanjutnya dapat membandingkan populasi dari sekolah yang berbeda jenis. Contoh: sekolah berasrama dengan sekolah tidak berasrama atau sekolah umum dengan sekolah berbasis keagamaan.

4. Dukungan sosial perlu diberikan kepada santri sehingga dengan dukungan sosial yang tinggi maka prestasi santri juga akan meningkat.

\section{DAFTAR PUSTAKA}

Azwar, 2017. Penyusunan Skala Psikologi Edisi II. Pustaka Pelajar, Yogyakarta.

Gräbel, 2017. The relationship between Wellbeing and Academic Achievement. Positive Psychology and Technology Department of Behavioral, Management \& Social Sciences University of Twente.

Gunarsa, S.D. \& Gunarsa, Y.S, 2000. Psikologi Remaja. BPK Gunung Muliat, Jakarta.

Halim \& Atmoko, 2005. Hubungan Antara Kecemasan akan HIV/AIDS dan Psychological Well Being pada Waria yang Menjadi Pekerja Seks Komersial. Jurnal Psikologi. Volume 15. No 1.

LvI, B, dkk, 2016. The Relationship between Academic Achievement and the Emotional Well-Being of Elementary School Children in China: The Moderating Role of Parent-School Communication. Frontiers in Psychology Volume 7. Article 948. 
Maslihah, S, 2011. Studi Tentang Hubungan Dukungan Sosial, Penyesuaian Sosial Di Lingkungan Sekolah Dan Prestasi Akademik Siswa Smpit Assyfa Boarding School Subang Jawa Barat. Jurnal Psikologi Undip Vol 10, No 2, Oktober 201.

Musthafa, A.I.I \& Widodo, P.B. Psychological Well Being Ditinjau dari Dukungan Sosial pada Santriwan-Santriwati di Yayasan AlBurhan Hidayatullah Semarang. Jurnal Psychology.

North West Adelaide Health Study, 2007. Cronic Condition Psychological Well Being: Epidemiological Series Report. Australia: The University of Adelaide Australian.

Rüppel, F, dkk, 2015. The Influence of Psychological Well-Being on Academic Success. J Public Health(2015)23:15-24. DOI 10.1007/s10389-015-0654-y.
Silalahi, 2015. Metode Penelitian Sosial Kuantitatif. Refika Aditama, Bandung.

Sugiyono, 2013. Metode Penelitian Kuantitatif, Kualitatif dan $R \& D$. Alfabeta, Bandung. Sugiyono, 2015. Metode Penelitian Kombinasi (Mixed Methods). Alfabeta, Bandung.

Suharsimi, 2006. Prosedur Penelitian Suatu Pendekatan Praktik Edisi Revisi VI. Rineka Cipta, Jakarta.

Suharsimi, 2010. Prosedur Penelitian Suatu Pendekatan Praktik. Rineka Cipta, Jakarta.

Sukmadinata, 2013. Metode Penelitian Pendidikan. Rosdakarya, Bandung.

Widanarti, N \& Indati, A. 2002. Hubungan Antara Dukungan Sosial Keluarga Dengan Self Efficacy Pada Remaja Di Smu Negeri 9 Yogyakarta. Universitas Gadjah Mada. Jurnal Psikologi, No. 2, ISSN : 0215 - 8884, 112-123.

Widoyoko, 2012. Teknik Penyusunan Instrumen Penelitian. Pustaka Pelajar, Yogyakarta. 